\title{
Therapeutic Proteins Derived from Recombinant DNA Technology
}

\author{
Mabroukah Faraj El-Taher and Al-Yaqeen*
}

Medical Laboratory- Hoon city- Libya

Faculty of Medical technology-University of Al-jufra-Libya

*Corresponding author

Keywords

Therapeutic

Proteins

Recombinant DNA

Article Info

Accepted:

15 December 2019

Available Online:

20 January 2020

\section{A B S T R A C T}

The main aim of this study is to critically investigate in current up-to-date the technology of rDNA and its biomedical applications as therapeutic proteins. rDNA is the new technology and is a field of molecular biology where scientist reshape the DNA to form synthetic molecular that help to cure many diseases related to human being. A therapeutic proteins are proteins engineered in laboratory for pharmaceutical purpose, making of insulin is one of the most important benefits ever could be achieved by this technology. Therapeutic proteins are also used in different treatment such as Anemia, Hemophilia, Cancer, Hepatitis B and C and many more. A specific host cell like Bacteria is required to generate rDNA technology based protein. These proteins have a huge impact not only in disease related to human but also benefits agricultural and industry, on the other hand, there is a huge safety concerns affiliated with rDNA such as Virus's developing treatment resistance. However, the future of rDNAproducts as therapeutic proteins is looking bright in term of new development in science and technology.

\section{Introduction}

A biotechnology is an industrial process that is being used for the scientific research on DNA for gaining practical benefits (Walsh, 2006). The new advancement of recombinant DNA (rDNA) technology and the tools affiliated has seen a rapid growth of biotechnology firms. Also, therapeutic rDNA products are now widely available for mankind use (Lyman and Dale, 2011). It has been acknowledged worldwide about the view of increasing importance of rDNA products for the betterment of human healthcare.

Biotechnology is always identical with genetic engineering because organism's genes are being changed during the process and forms recombination of DNA (Potvin and Zhang, 2010). Biotechnology and rDNA can be used for variety of purposes such as to form protein which is not usually produced in 
a normal cell activities. Bacteria those carry rDNA can help to increase the fertility of the soil by releasing it into the environment which is the mostly favorable solutions in decreasing pollution or serve as an insecticide (Javris, 2008).

A therapeutic proteins are proteins that are engineered in the laboratory for pharmaceutical purpose in making of insulin to treat diabetes almost a decade ago in the early 1920s (Bhopale and Nanda, 2005). With the recent development in science and technology has encouraged a number of biotechnology-driven proteins used as therapeutic agents (Vlieghe et al., 2010). Further, there are many factors that also may influence the immunogenicity of therapeutic proteins which can be considered as two main factors such as product related or patient related. A patient related factor is the response of immune system include genetic background, immune status, underlying disease and dosing schedule (Bhopale and Nanda, 2005).

Product related factor include of formulation, stability characteristics and manufacturing process that can also influence the likelihood of immune response. However, more study on possible factors to therapeutic proteins are also required prior to marketize the authorization. It can be possible found during the post-authorization period that often improve the enhancement. According to (Potvin and Zhang, 2010) a systematic immunogenicity testing can be useful for more authentic process after marketing authorizations and may include in risk management plan as well.

rDNA technology based protein can be generated in specific hosts cell like bacteria if preconditions are defined (ProBioGens, 2011a). A mammalian cells are the most favorable choices among many practitioners to host the cells because their posttranslational modifications have the biggest factors of the protein's pharmacokinetics and efficiency of the modifications. Figure 1 below shows different development platform for the pharmaceutical cell line development are suggested by ProBioGen (2011a) laboratory includes Host Cell Line, Vector Technology, Regulatory Compliance, and Media Platform.

A Host Cell Line development can produce optimal clone development because of its later efficiency where Chinese Hamster Ovary $(\mathrm{SCH})$ is the most common example of cell produced in commercial biopharmaceutical production (Antosova et al., 2009). Vector technology is based on sophisticated transgene and codon optimization which results in a rapid identification of top performing clones production system and help to minimizing workload of screening and project timelines (ProBioGens, 2011a). Media platform is another kind of successful cell line development which is medium and balanced formulation of all relevant nutrients, trace elements and vitamins (ProBioGens, 2011a).

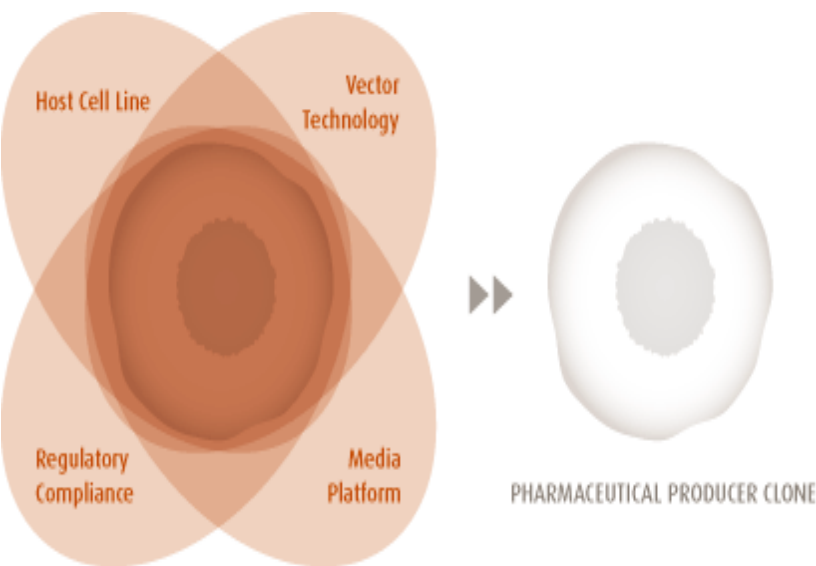

Figure.1 Cell Line Development Platform (Source: ProBioGens, 2011a)

Therapeutic proteins are used in different treatment (ProBioGens, 2011b) such as:
$\checkmark$ Anemia
$\checkmark$ Cancer 
$\checkmark$ Hemophilia

$\checkmark$ Hepatitis B and C

$\checkmark$ Infectious Diseases

$\checkmark$ Multiple Sclerosis

Production of pharmaceutical by advance technology for therapeutic purposes shows great promises during clinical trials. There are many investigation underway that can easily expand to provide lower cost of production relative to the cell culture system which is currently used to produce biological therapeutic.

\section{Recent Pharmaceutical Market Evolution}

rDNA technology is widely used in the production of therapeutic agent which include antibiotics, growth factors, hormones, vaccines, albumin, and many more. All mentioned and many others therapeutic agents can easily produce in a large number by using rDNA technology where many proteins helped medical treatment or for further research at very low concentrations (Kaushansky, 2006). There are a large number of methods used in the pharmaceutical market to produce recombinant proteins such as microbial bioreactors, mammalian cell derived bioreactors, and animal bioreactors (i.e. also known as pharming) are few examples.

These days'rDNA evolution can be seen in famous Hollywood movies such as Spiderman, Jurassic Park, Rise of the Planet of the Apes, and many more. In famous movie Spiderman shows how a mutant spider bite and passed its spider genes into human body by giving a super strength, web-slinging actions and visions (Shmoop, 2013). In this case the Spiderman exists because of rDNA entered into human genome.

Unfortunately, the methods showed in the movies are not actually performed in a real world but in fact that it features rDNA. Similarly, making rDNA also involves taking gene, from a eukaryote and passed into a bacterial plasmid (Kaushansky, 2006). However, these movies showed a negative side of the technology or scientist who were involved in doing something evil by using rDNA. In fact, movies cannot be blamed for being bad used on this concept because the concept of movies are just to entertain people not sometime showing the exact nature of the technology or benefits. There are many applications related to rDNA technology such as medical application, gene therapy and vaccines, creation of genetically modified corps, making extra minerals and vitamins, bacteria that can help clean oil spill, and even making of fake snow.

Figure 2 below shows the techniques that actually being used by scientists to make proteins and deliver genes for numerous biotechnology applications.

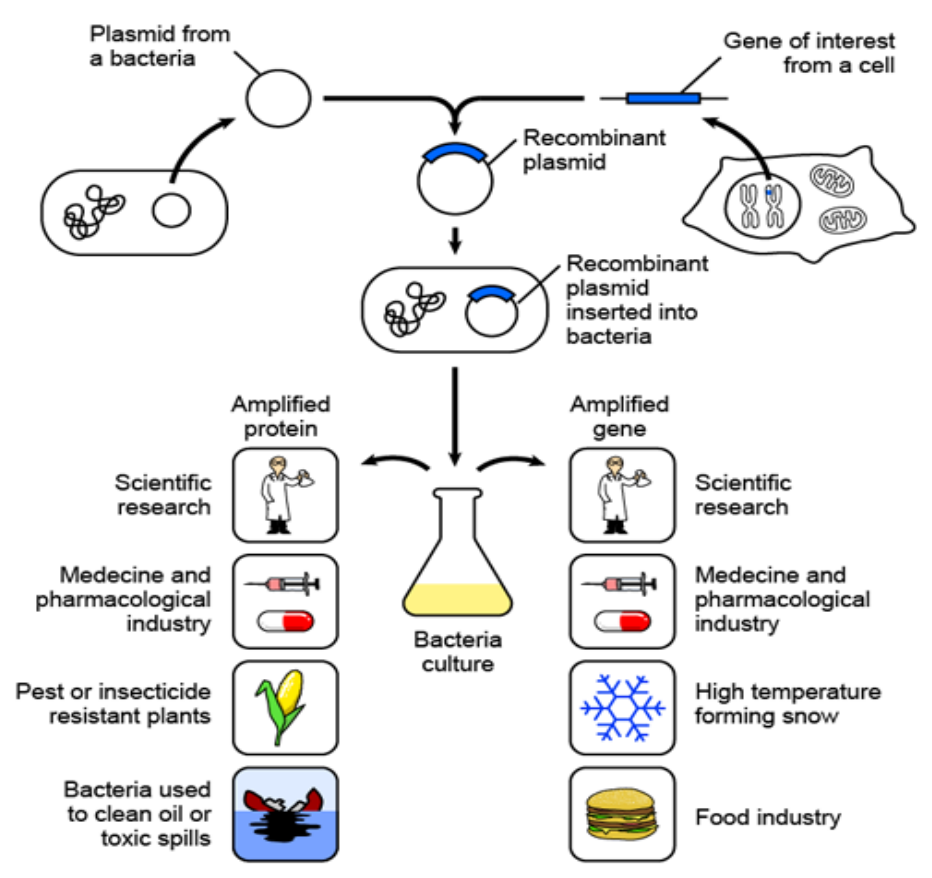

Figure.2 Application Process of rDNA Technology (Source: Azencott, Peter and Prausnitz, 2007) 
Production and purification of rDNA products

Figure 3 below illustrates a general process for the production of rDNA products where the first step involved to identify gene that is responsible for the expression of the desired products. In the second stage, a human gene isolated and characterized and then inserted into small pieces of DNA called plasmid (Bhopale and Nanda, 2005) then recombinant plasmid inserted into a bacterial yeast or cultural animal cell.The clones are then isolated to produce the protein of interest in the desire quality under the suitable condition which can be further used in subsequent transformation procedures. It is useful method in the determinations of identity of making pure and potent of rDNA products in safe and effective medicine for human use. The use of therapeutic applications to replace endogenous protein molecules has been a well-known treatment for diseases. Moreover, cell bank can be periodically tested for cell viability, genetic and phenotypic stability as shown in figure 3 below.

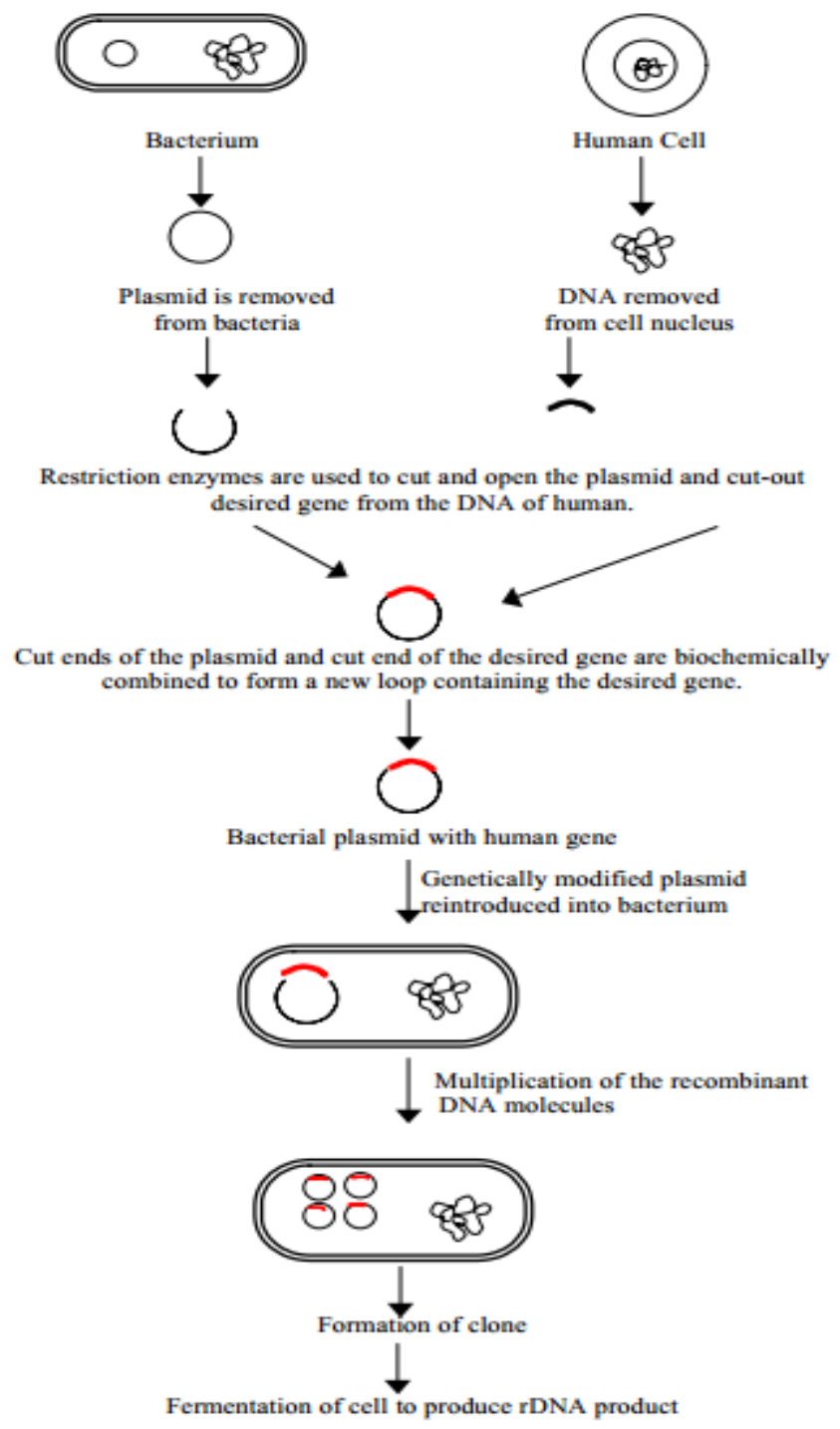

Figure.3 rDNA Technology for Production of Human Therapeutics Proteins (Bhopale and

Nanda, 2005) 
Table.1 FDA approved rDNA products for human therapeutic use (Source: Bhopale and Nanda, 2005).

\begin{tabular}{|c|c|c|c|}
\hline Therapeutic Category & Products & Expression Host & Abbreviated Indications \\
\hline \multirow[t]{5}{*}{ Haemopoietic growth factors } & Erythropoietin Alpha & $\mathrm{CHO}$ cells & $\begin{array}{l}\text { Treatment of anemia associated with } \\
\text { renal failure, HIV infection cancer. }\end{array}$ \\
\hline & Erythropoietin Beta & CHO Cells & $\begin{array}{l}\text { Treatment of anemia associated with } \\
\text { renal failure }\end{array}$ \\
\hline & Darbepoetin & CHO Cells & $\begin{array}{l}\text { Treatment of anemia associated with } \\
\text { renal failure and cancer. }\end{array}$ \\
\hline & Filgrastim & E. Coli & $\begin{array}{l}\text { Reduction in duration of neutropenia } \\
\text { and incidence of febrile neutropenia in } \\
\text { patients treated with cytotoxic } \\
\text { chemotherapy for malignancy. }\end{array}$ \\
\hline & Surgramostism & S. Cerevisiae & Treatment of neutrophil recovery. \\
\hline \multirow{6}{*}{$\begin{array}{l}\text { Hormone of therapeutic } \\
\text { interest }\end{array}$} & Human insulin & E.Coli/S. cerevisiae & Treatment of diabetes. \\
\hline & Insulin aspart & S. cerevisiae & Treatment of diabetes. \\
\hline & Insulin glargine & E.Coli & Treatment of diabetes. \\
\hline & Insulin lispro & E.Coli & Treatment of diabetes. \\
\hline & Insulin glulisine & E.Coli & Treatment of diabetes. \\
\hline & $\begin{array}{l}\text { Human } \\
\text { choriogonadotropin }\end{array}$ & $\mathrm{CHO}$ cells & $\begin{array}{l}\text { Treatment of women undergoing } \\
\text { superovulation prior to assist } \\
\text { reproductive techniques such as in vitro } \\
\text { fertilization. }\end{array}$ \\
\hline Anticoagulants & Lepirudin & S. cerevisiae & $\begin{array}{l}\text { Anticoagulation therapy for heparin } \\
\text { associated thrombocytopenia. }\end{array}$ \\
\hline \multirow[t]{2}{*}{ Human interleukins } & Interleukin-2 & E.coli & Renal cell carcinoma. \\
\hline & Interleukin-11 & E-Coli & Treatment of thrombocytopenia. \\
\hline
\end{tabular}

FDA (2014). U.S. Department of Health and Human Services. [Online]. Available at: http://www.fda.gov/default.htm 
The table indicates the most tested rDNA products in use for human therapeutic which has been approved from the United States FDA (Food and Drug Administration).

\section{Haemopoietic growth factors}

Haemopoietic growth factors is a major recombinant technology that can be used for the treatment of anemia associated with renal failure, cancer, surgery and HIV infections (Smith et al., 2006). Further, there are three main haemopoietic growth factors such as HGFs are erythropeitin (EPO) which are commonly used to increase red blood cell (RBC) production in human body, granulocyte colony-stimulating factor (GCSF) and granulocyte-macrophage colonystimulating factor (GM-CSF) is used to increase granulocyte production (Kim, Kim and Lee, 2011). However, the research is still going on in similar recombinant technologies because the current shape of the technology is expensive and also major factors are in clinical trial (Lyman and Dale, 2011).

Most of the HGF (Haemopoietic Growth Factor) are very helpful for those patient who have very low blood count. However, there are some drawbacks with these new advancement in patient treatment related medicines as well. It is highly well tolerated but still there are chances diarrhea and fluid retention may occurs. Further, hypertension can also be visible in sometime especially with those patients who have suffering with renal failure and underlying hypertension (Smith and Sturm, 2010).

\section{Hormones of therapeutic interest}

Recently it has been observed that the most common disease is diabetes mellitus in the world which is characterized by hyperglycemia and main caused is because of insulin action or insulin secretion (Hughes,
2009). There was a time when these disease were very dangerous and there was no proper medication available to cure these type of diseases (Guzman et al., 2007).

However, now due to new advancement in biotechnology and rDNA advancement make it possible to develop new medicines to cure these diseases without any major side effects. Different research is still going on in this area because the most structural modifications of this method allow it to dissolve in an acidic solution such as insulin lispro produced in E.coli (Hughes, 2009). The most practical benefit of this therapy is to control disease related to diabetes and blood-glucose lowering agent.

\section{Anticoagulants}

Anticoagulants is a treatment method which is based on advanced technology to prevent blood clots that may occurs in patient blood vessel where Warfarin is the most common method used in this regard (DiMasi and Grabowski, 2007). Advance technology in biotechnology make it possible for anticoagulant which can be further used for more and better results for better blood test which can monitor blood clots.

Blood clots are sometime caused to block an artery or a main vessel that connect to the human heart, in such situation blood and oxygen from getting to a part of patient body stop which is dangerous and cause serious health problem including death (NHS, 2014).

This is the most significant treatment by using advanced treatment, however; there are few things which need to be seriously considered before taking this treatment. Like some anticoagulant medicines are not suitable for pregnant women and must be discussed with GP before even planning to use it for treatment. Further the method also not 
pleasant for those who are taking an endoscopy because it can cause excessive bleeding.

\section{Human interferon}

There are three main recombinant human interferon (rhuIFN), these are alpha, beta and gamma. alpha-2b is properly approved for the treatment for hairy cell treatment, hepatitis B and $\mathrm{C}$ and many more diseases (DiMasi and Grabowski, 2007). rhuIFN beta-1bis famous for first line therapeutic treatment in relapsing multiple sclerosis. The third one is rhuIFN gamma is produced from E. coli which contained 139 amino acids and used to indicate in reducing the frequency and severity of serious infection (Hughes, 2009).

There are a lot of health related benefits to human in curing diseases such as it is interferon modulate of the response to the immune system such as viruses, cancer, and bacteria which are the most complex foreign substances that can invade human body.

There are range of benefits of using this technology in pharmaceutical because it is a naturally-occurring proteins that are developed and secreted by cells of the immune system, however; there are many drawbacks. The most serious are flulike symptoms of fever and fatigue, there are chances to decrease the production of blood cells by bone marrow.

It is basically a commercially available which is manufactured by using rDNA technology and is a complex process. According to Medicine Network (2014) interferon's is not directly killing or destroying the cancerous cells but thy boost the human immune system response and eventually it will reduce the risk and regulating the action in order to control the further secretion of several cellular proteins which may grow later.

\section{Future of rDNA products}

The future of rDNA products as a therapeutic proteins is looking bright in term of new development in science and technology.Currently one estimated that more than hundreds companies are involved in the development and marketing of rDNA products.As, discussed earlier that rDNA is the new technology and is a field of molecular biology where scientist reshape the DNA to form a synthetic molecular that help to cure many diseases related to human being.

If we go back to hundreds years we found that the cutting, pasting and copying DNA is not really a new phenomenon because Arthur Kornberg's successfully replication of viral DNA was a breakthrough which also led to the concept cloning (Shivanand and Noopur, 2010). However, at that time there was no such an advance technology and computer system which can record millions of record in a blink of second. There are many concerns also affiliated with this new technology such as rDNA to be used in bad and good purposes. rDNA has a huge impact on future if used in a good way.

The most important benefits ever could be achieved by using this new advanced technology are listed below:

rDNA helped to improve the field of Medicines.

It also helped in to resist to disease or in other world improved the Livestock.

It is not only help human being to cure their disease but also helped in crops (resistance to diseases and higher yields).

Further, it also improve the prevention methods of genetic diseases. 
rDNA reduced the medicine cost such as insulin.

rDNA is being used in many treatment for pre-existing conditions such as Cancer. (Shivanand and Noopur, 2010).

There are few bad things could be happened with using of rDNA as follow in below list:

There is a huge safety concerns affiliated with rDNA such as virus's developing antibiotic resistance.

There are environmental concerns for example the developing resistance to fungi.

There are also concerns from religious to this technology because of ethical dilemmas over the way of human treatment and human cloning.

Many reports are recorded where doctors used their patients as test subject which is potentially for experimental abuse. (Shivanand and Noopur, 2010).

rDNA is an artificial development which is created from one or more DNA combined into single molecular, the technique is also known as genetic engineering, recombinant DNA technology. The technology have a huge impact in the field of medicine of new dimension, which resulted into the large number of production of biochemically derived proteins. These biochemically developed proteins have a significant impact on pharmaceutical industry worldwide. The biochemically derived therapeutic proteins have a huge amount of usage not only in preventing diseases related to human but also benefits agricultural industry.

These rDNA based therapeutic proteins are considered chronically replacement therapies or for the treatment of life threatening diseases such as Cancer. Further, these important applications of rDNA in the area of human disease are diagnosis and discovery, and therapy related where different vaccines are developed. Moreover, there are advantages and limitation of this advancement in biotechnology. The most beneficiary to this technology is the Livestock and agricultural industry where this technology is being used in treatment of life threating diseases such as cancer etc. However, there are limitations if these advancement not used in right direction such as the ethical and environmental concerns as discussed.

\section{References}

Antosova, Z. et al., (2009). Therapeutic application of peptides and proteins. parenteral for ever? Tends Biotechnology, Vol. 27, pp. 628-635.

Azencott, H.R., Peter, G.F. \&Prausnitz, M.R. (2007). Influence of the cell wall on intracellular delivery to algal cells by electroporation and sonication. Ultrasound Med Biol, Vol. 33, pp.1805-1817.

Bhopale, G.M. \& Nanda, R.K. (2005). Recombinant DNA expression products for human therapeutic use. Research and Development Division, Current Science, Vol. 89 (4), pp. 614-622.

DiMasi, J.A. and Grabowski, H.G. (2007).The cost of biopharmaceutical $R \& D$ : is biotech different?Manag. Decis. Econ. Vol. 28, pp. 469-479.

Hughes, B. (2009).2008 FDA drug approvals: a year of flux. Nat. Rev. Drug Discov. Vol. 8, pp. 93-96.

FDA (2014). U.S. Department of Health and Human Services. [Online]. Available at: http://www.fda.gov/default.htm

Guzman, F. et al., (2007).Peptide synthesis: chemical or enzymatic. J. Biotechnol. Vol. 10, pp. 279-314.

Jarvis, P. (2008). Targeting of nucleusencoded proteins to chloroplasts in plants. New Phytol,Vol. 79, pp. 257-85.

Kaushansky, K. (2006). Lineage-specific hematopoietic growth factors. N Engl J 
Med, Vol. 354, pp. 2034-2045.

Kim, J.Y., Kim, Y. \& Lee, G.M. (2011). CHO cells in biotechnology for production of recombinant proteins: current state and further potential. ApplMicrobiol Biotechnol, Vol. 93, pp. 917-930.

Lyman, G. \& Dale, D.C. (2011). Hematopoietic growth factors in oncology. In: Rosen ST, ed. Cancer Treatment and Re-search. New York, NY: Springer Science.

Medicine Network (2014). Interferon. [Online]. Available at: http://www.medicinenet.com/interferon/ article.htm

NHS (2014). Anticoagulant Medicines. [Online]. Available at: http://www.nhs.uk/conditions/Anticoag ulantmedicines/Pages/Introduction.aspx

Potvin, G. \& Zhang, Z. (2010). Strategies for high-level recombinant protein expression in transgenic microalgae: A Review. Research Review Paper, Science Direct, Biotechnology Advances, Vol. 28, pp. 910-918.

ProBioGen (2011a). Pharmaceutical Cell Line Development. [Online]. Available at: http://www.probiogen.de/services/thera peutic-proteinsantibodies/productioncell-lines.html (Accessed: 11 November
2014).

ProBioGen (2011b). Therapeutic Proteins/ Antibodies. [Online]. Available at: http://www.probiogen.de/services/thera peutic-proteinsantibodies.html

Shivanand, P. \&Noopur, S. (2010). Recombinant DNA Technology: Applications In The Field Of Biotechnology And Crime Scenes. International Journal of Pharmaceutical Science Review and Research, Available online at: www.globalresearchonline.net, Vol. 1(1), pp. 43-49.

Shmoop (2013). DNA Structure, Replication, and Technology. [Online]. Available at: http://www.shmoop.com/dna/recombina nt-dna.html (Accessed: 20 November 2014).

Smith, V.H. \& Sturm, B.S.M. (2010). The ecology of algal biodiesel production. Trend EcolEvol, Vol. 25, pp. 301-309.

Vlieghe, P., Lisowski, V., Martinez, J., and Khrestchatisky, M. (2010). Synthetic therapeutic peptides: Science and Market. Drug Discovery Today, Vol. 15 (1\&2), pp. 40-56.

Walsh, G. (2006). Biopharmaceutical benchmarks 2006. Nat. Biotechnol, Vol. 24(7), pp. 769-776.

\section{How to cite this article:}

Mabroukah Faraj El-Taher and Al-Yaqeen. 2020. Therapeutic Proteins Derived from Recombinant DNA Technology. Int.J.Curr.Microbiol.App.Sci. 9(01): 2024-2032. doi: https://doi.org/10.20546/ijcmas.2020.901.229 